\title{
Erindringer fra redaktionsarbejdet med Sønderjyske Årbøger
}

\author{
af Peter Kr.Iversen
}

\section{Trykkeri}

Da jeg 1946 som nybagt sekretær i Historisk Samfund for Sønderjylland også skulle overtage hvervet som redaktionssekretær for Sønderjyske Årbøger, var mit kendskab til bogudgivelser og bogtrykkerarbejde meget begrænset. Jeg havde fået et par større artikler trykt $\mathrm{i}$ årbøgerne, en mindre i Sønderjysk Månedsskrift og udgivelsen af min lille vejledning i lokalhistorisk arbejde og af de Vogelgesang'ske aktstykker var på trapperne. Direkte samarbejde med trykkerier havde jeg endnu ikke været udsat for. Det måtte jeg i gang med nu, og efterhånden har jeg da også fået et ret indgående kendskab til »den sorte kunst«, et udtryk der med ibrugtagningen af de nye teknikker inden for bogfremstillingen vel er ved at gå i glemmebogen.

Jeg fik ved mit redaktionsarbejde med Sønderjyske Årbøger og bøger gennem mange år et nært samarbejde med Hejmdals bogholder Johan R.Skov og senere med forretningsfører H. Ipsen og med hensyn til Sønderjysk Månedsskrift og en række bøger i skriftrækken, et fortrinligt samarbejde med Th.Laursen i Tønder, hans hustru og senere de to sønner, Svend Aage og Børge. Det var to vidt forskellige trykkerier, det ene allerede til en vis grad i afvikling og det andet inde $i$ en kraftig udvikling og modernisering. Begge steder var der noget at lære.

Sønderjyske Årbøger var fra 1901 blevet trykt i Hejmdals bogtrykkeri og ved Historisk Samfunds overtagelse af udgivelsen 1923 fortsattes med trykningen her. $\mathrm{Da}$ jeg jo var bosat i Aabenraa, kunne jeg personligt aflevere manuskripterne til J.Skov og kunne med ham mundtligt aftale opsætning, korrektur, klicheers placering og ombrydningen i det hele taget. Jeg fik forklaret og forevist både, hvordan man lavede håndsats og maskinsats, lærte navnene på de forskellige skrifter og brugen af de forskellige trykkerimaskiner at kende og samtidig også en del af Hejmdals faste stab af typografer. Ofte har jeg ført samtaler med den elskelige faktor C. Boldt, der på sine gamle dage til tider kunne virke lidt forvirret, men som $\mathrm{i}$ en lang årrække havde været avisens og trykkeriets solide tekniske ankermand. Fra de senere år mindes jeg 
samarbejdet med Hoff og Peter Bodum, dygtige og meget hjælpsomme folk, der aldrig var bange for at tage en ekstratørn, når noget skulle være færdig til en bestemt tid.

Der kunne i de første år efter besættelsen, da der endnu var knaphed på brændsel, være store spændingsforskelle i strømleverancen fra højspændingsværket, og det kunne derfor hænde, at sættemaskinerne, der jo arbejdede med elektricitet, præsterede en meget uregelmæssig og uskøn sats, som til tider først afsløredes ved rentrykningen. Denne måtte derfor afbrydes, for at der kunne fremskaffes en ny sats. Hele og halve sider måtte i stor hast sættes om, uden at jeg og i flere tilfælde måske også Skov fik lejlighed til at læse en ny korrektur. Det kan derfor heller ikke udelukkes, at der herved i nogle årgange vil være en del ekstra trykfejl, som jeg i nogen grad må siges at være sagesløs overfor.

I sammenligning med Th.Laursens trykkeri må Hejmdals maskinpark siges at have været noget antikveret, for at bruge et mildt udtryk, og det var først efter at Ipsen var tiltrådt som forretningsfører, at der blev anskaffet mere moderne maskiner, bl.a. en trykkemaskine, der leverede smukt og godt arbejde. Trykningen af Sønderjyske Årbøger på Hejmdals trykkeri ophørte ved dets nedlæggelse 1972, og derefter er den overtaget af P. J.Schmidts bogtrykkeri i Vojens, men allerede det følgende år gik jeg ud af redaktionen.

Alt $i$ alt kan jeg se tilbage på et godt og behageligt samarbejde med Hejmdals ledelse og dets tekniske medarbejdere. Også trykkeriets altmuligmand og bud, Magnussen, der ligesom Ipsen kunne bringe korrektur ud til ekspresekspedition på de mærkværdigste tider af døgnet, bør nævnes i denne forbindelse.

\section{Redaktion}

Men selv om den rent tekniske fremstilling af Sønderjyske Årbøger for en nybagt redaktionssekretær var et interessant kapitel, måtte selve redaktionsarbejdet dog vare det væsentligste. Årbogsredaktionen bestod ved min tiltrædelse 1946 af Historisk Samfunds formand, amtslæge, dr.med. H.Lausten-Thomsen, højskoleforstander Hans Lund, Rødding, landsarkivar Johan Hvidtfeldt, min forgænger som sekretær og redaktionssekretær og så min ringhed. Efter Historisk Samfunds overtagelse af udgivelsen af Sønderjyske Årbøger 1923 udkom disse i to halvbind årligt, et forårshæfte, der udsendtes omkring 1. maj og et efterårshæfte, der skulle udkomme i november, men sjældent kom før hen $\mathrm{i}$ december, idet trykningen af Sønderjyske Årbøger ofte kolliderede med trykningen af Sprogforeningens Almanak og $Æ$ Rummelpot. Ved min 
overtagelse af redaktionssekretærhvervet skulle jeg altså i gang med efterårshæftet, men det stod da lidt sløjt til med brugbare manuskripter, og for at få efterårshæftet fyldt, måtte jeg derfor straks gå i gang med at få et ikke fuldt færdiggjort manuskript af pastor Carsten Petersen om slesvigske præstegårde afpudset og gjort trykklart, hvilket skete i samarbejde med biskop Noack og pastor Aaholm, Vojens. Manuskriptet havde et omfang på knap 70 sider og fyldte dermed et godt hul $\mathrm{i}$ efterårshalvbindet, som endvidere omfattede afslutningen af en stor afhandling om arkitekten L.A. Winstrup af dommerfuldmægtig Erik Bondo Svane, der døde i Neuengamme. Jeg var således med til i det første halvbind af Sønderjyske Årbøger, som jeg var med til at redigere, at publicere afhandlinger af to mænd, som jeg begge havde personligt kendskab til, og som hver på sin måde havde øvet en indsats $i$ landsdelens historie.

Som den unge og uerfarne mand, jeg var, måtte det naturligvis være en oplevelse at indtræde $\mathrm{i}$ et samarbejde med så fremtrædende historikere og personligheder, som de øvrige tre medlemmer af redaktionen var. Formanden, dr. Lausten-Thomsen var meget produktiv som folkelig historisk og litterærhistorisk forfatter og var en meget benyttet foredragsholder trods sin noget snøvlende stemme. Han lagde megen vægt på, at afhandlingerne var læselige for et bredt publikum, og at de var skrevet på et godt dansk sprog uden germanismer, som han afskyede som pesten. Derfor måtte der også holdes strengt på, at Historisk Samfund ikke havde en bestyrelse, men en styrelse. Hans sprogøre havde en gavnlig indvirkning på sproget i mange af de afhandlinger og artikler, som blev publiceret $\mathrm{i}$ årbøgerne $\mathrm{i}$ de mange år, hvor han var med i redaktionen - fra 1923 til 1956, altså i 33 år. Han var omhyggelig i sin gennemgang og vurdering af manuskripterne, som aldrig fik lov til at ligge ret mange dage hos ham.

Det samme kan ikke siges om forstander Hans Lund, der havde været med i årbogsredaktionen fra 1928. Han var historiker af fag og nød betydelig anseelse. Især var han kendt for sin skildring af den nationale og politiske udvikling i tiden 1864-1920 i den store Sønderjyllands Historie. Også som foredragsholder var han kendt ikke blot $i$ landsdelen, men tillige gennem sine radioforedrag i langt videre kredse. Dr. Lausten-Thomsen og Hans Lund var personligheder, man uvilkårligt på baggrund af deres indsats i det folkelige og nationale arbejde måtte se op til. Men det blev dog efterhånden med lidt blandede følelser, at jeg kom til at se på Hans Lunds medvirken i årbogsredaktionen. Han havde som forstander og foredragsholder alt for meget at rive $i$, og det blev umuligt for ham at få manuskripterne læst og kommenteret i blot nogenlunde rimelig tid. Og jeg fik næsten det indtryk, at han af princip ikke svarede på breve. Når jeg havde skrevet til ham i et eller andet ærinde, måtte 
jeg derfor som regel et par dage senere tage telefonen for at få svar eller accept på mine spørgsmål og forslag. Han var efter på så mange måder at have ydet en værdsat indsats $i$ landsdelens historiske arbejde efterhånden ikke noget ubetinget aktiv at have med $\mathrm{i}$ årbogsredaktionen, og derfor gled han også ud af denne ved foreningens omstrukturering i 1955.

Det tredie medlem af redaktionsudvalget var den tidligere redaktionssekretær fra 1941, landsarkivar Johan Hvidtfeldt, Viborg. Det, der i første omgang havde præget hans periode som sekretær 1941-46 var, at der blev bragt flere og meget kvalificerede anmeldelser af større værker og endvidere gode oversigter over den mere jævne historiske litteratur vedrørende sønderjyske emner. Navnlig blev der lagt vægt på orienteringen om, hvad der fremkom fra tysk side. Kort efter hans tiltræden som redaktionssekretær fik jeg 1942 min første afhandling optaget, og dermed var min medvirken ved Sønderjyske Årbøger begyndt. I langt de fleste af de følgende årgange har jeg derefter bidraget med et eller andet, $\mathrm{i}$ hvert fald har jeg vel $\mathrm{i}$ tredive år skrevet foreningens årsberetninger. De retningslinier, Johan Hvidtfeldt havde lagt, blev fulgt af mig; idet jeg dog nok forsøgte at få flere anmeldelser af lokalhistorisk litteratur

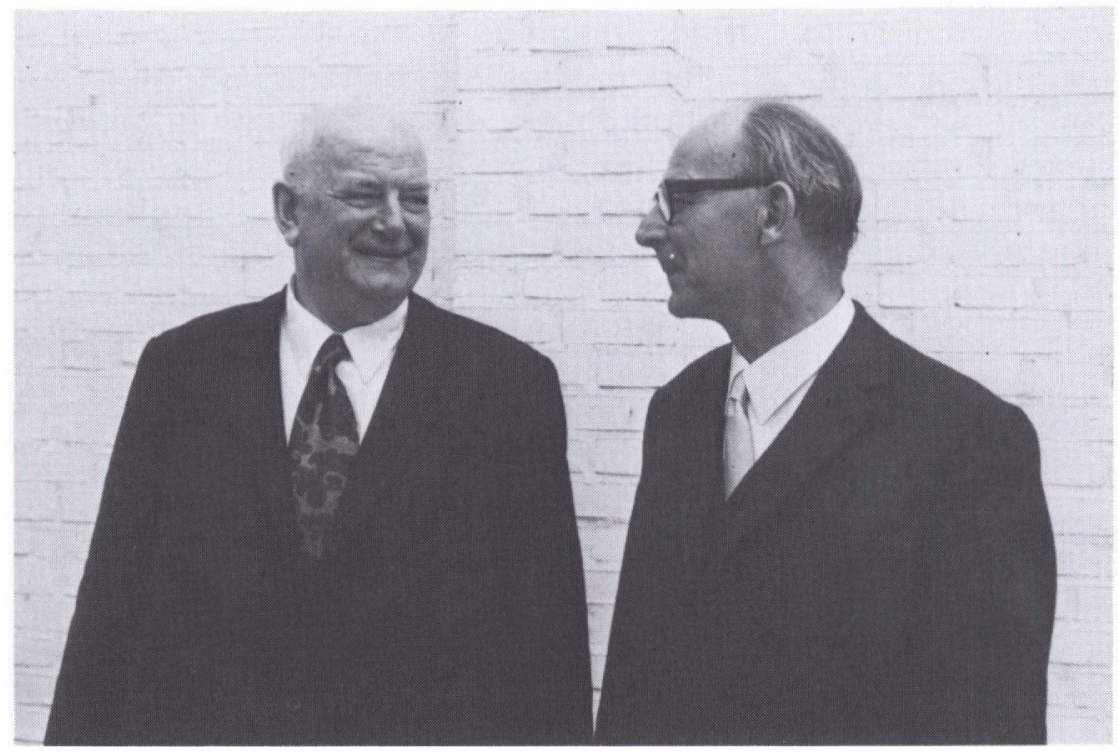

To gode venner. Rigsarkivar, dr.phil. Johan Hvidtfeldt og landsarkivar Peter Kr.Iversen havde i mange ar et meget snavert samarbejde, ikke blot $i$ redaktionen af Sonderjyske Arboger og $i$ styrelsen for Historisk Samfund for Sonderjylland, men ogsd inden for Dansk historisk Fallesforening.

Fot. 1972 ved Historisk Samfunds dirsmode i Tonder. Historiske Samlinger, Aabenraa. 
og også prøvede på at samle nogle skrifter til en sammenlignende vurdering. Jeg selv søgte at give opmuntrende anmeldelser, som kunne være med til at vække andres lyst til at gå $i$ lag med et lokalhistorisk arbejde.

Min tid som redaktionssekretær for Sønderjyske Årbøger varede til efterårshæftet 1955, og jeg havde i disse år den glæde, at ikke færre end tre gange blev afhandlinger tildelt Dansk historisk Fællesforenings årbogspris, nemlig 1947 til Chr.Stenz, 1949 til H.V.Gregersen og 1952 til A.Svensson, hvilket jo i hvert fald må kunne tages som udtryk for, at Sønderjyske Årbøger havde en vis kvalitet. Derefter overtog daværende adjunkt, senere rektor Knud Fanø hvervet, der hidtil havde været kombineret med foreningens sekretærstilling. I de mange år siden da har Fanø trods sine mange andre gøremål på forbilledlig vis sørget for årbøgernes udgivelse, $\mathrm{i}$ de senere år dog på delt arbejde med Dorrit Andersen og Lars Henningen.

\section{Nye rubrikker}

I fortrinligt samarbejde med Fanø og Johan Hvidtfeldt gennemførtes i de følgende år ændringer i Sønderjyske Årbøgers indhold og ydre. Uden at dr. Lausten-Thomsen ville tillade et særligt afsnit, der skulle omfatte korte omtaler af nyligt udkomne bøger, der $\mathrm{i}$ almindelighed ikke kunne tilkomme en egentlig anmeldelse, et afsnit eller rubrik, som Hvidtfeldt og jeg gerne ville kalde Bognyt, var jeg i det små - hæftet på de egentlige anmeldelser - 1952 begyndt hermed. På grund af pladsnød måtte en række anmeldelser udgå 1953, og i stedet kunne jeg da under den nye rubrik Bognyt nævne de nye udkomne bøger, hvoraf en del senere ville få en egentlig anmeldelse, og 1954 kom så det første regulære afsnit Bognyt. I denne rubrik har redaktionen derefter år for år kunnet holde læserne underrettet om navnlig små lokalhistoriske og personalhistoriske skrifter og tillige også ved lejlighed om bøger, som kun periferisk havde interesse for årbøgernes sønderjyske læsere.

En anden rubrik var jeg også meget interesseret $i$ at få oprettet, nemlig den, der fik navnet Noter og Nyt, som første gang fandtes i årbogen 1957. Rubrikken var og blev, som det også var meningen, af meget blandet indhold. Den bragte nekrologer over medlemmer af styrelsen og over andre, som havde udført en værdifuld indsats i landsdelens historiske arbejde. Snart fulgte også fødselsdagsartikler ved runde år. Endvidere bragtes korte beretninger fra arkiver og museer, om udgravninger og udstillinger, om egnsvandringer og historiske søndage og om amtskredsenes arbejde - for blot at nævne nogle af de vigtigste emner, som blev omtalt her. Knud Fanø har gjort et stort arbejde for at få denne rubrik så fyldig som muligt, og der har sikkert til tider 
måttet anvendes et ikke alt for diplomatisk sprog for at få disse mange små beretninger rettidig frem.

\section{Årbøgernes ydre}

Sønderjyske Årbøger udsendtes fra 1934 i to halvbind i et trist gråt omslag, hvor der på de to sider var nogle få støtteannoncer, som det $\mathrm{i}$ sandhedens interesse efterhånden ikke kunne betale sig at bringe. Årbøgernes udseende havde i nogle år irriteret mig en del, men jeg havde på grund af formanden, dr. Lausten-Thomsens noget konservative syn med hensyn til en ændring af ydre og opsætning måttet holde mig afventende her. Navnlig svenske, men til en vis grad også norske lokalhistoriske årbøger og skrifter lå med hensyn til ydre og opsætning et hestehovede foran danske årbøger og altså også Sønderjyske Årbøger. Meget belejligt blev der da på årsmødet 1956 fremsat kritik desangående, en kritik der vel nok i nogen grad var fremprovokeret af mig, takket være mit fortrolige forhold til redaktør Morten Kamphövener. Kritikken blev taget op i redaktionen og på styrelsesmødet den 18. november 1956, og resultatet af drøftelserne var allerede synligt på forårshæftet 1957. Her var der ikke blot en mere moderne typografi, men det mest iøjnefaldende var vel nok, at omslaget nu var trykt på krideret kunsttrykpapir. Årbogens navn var her anbragt på nederste trediedel i blindtryk på sort baggrund, og de to øverste trediedele af forsiden var udstyret med et billede. Det var hensigten, at der skulle fremstilles et nyt billede til hvert halvbind. Disse illustrationer fremstilledes på gammeldags manér som zinkklicheer, der havde en holdbarhed på 1520 år, når de opbevaredes under gunstige forhold godt indsmurt $\mathrm{i}$ fedt. Min tanke var at gemme disse klicheer for senere at anvende dem samlet til fremstilling af en billedbog. Imidlertid lykkedes det at få billedbogen fremstillet på anden måde. Men det er en helt anden historie. Årbogens nye udseende kom til at danne skole, idet andre amtshistoriske samfund nu også begyndte at fikse deres årbog op.

Senere dukkede spørgsmålet om udsendelsen af Sønderjyske Årbøger i ét indbundet bind op. Vi havde haft gode erfaringer med at lade bøgerne $i$ skriftrækken indbinde i stift bind, som takket være en ny teknik kunne ske til en meget favorabel pris. Erfaringen viste, at kun de færreste af vore medlemmer lod deres årbøger indbinde, og at der som følge heraf let forsvandt hele eller halve årgange. I det hele taget fandtes der blandt private vel kun ganske få komplette eksemplarer af årbogen. Jeg havde derfor ved lejlighed luftet tanken om en ændring i udsendelsen af årbogen, men denne ændring stødte dels på den vanskelighed, at indbydelsen til årsmødet en af de sidste søndage i maj 
bekendtgjordes på forårshalvbindets omslag og dels på, at redaktionssekretæren, rektor Fanø, meget forståeligt mente, at redaktionsarbejdet for ham ville blive for koncentreret $\mathrm{g}$ forceret $\mathrm{i}$ årets sidste måneder. Takket være Fanøs store arbejdskraft, og ved at få arbejdet bedre delt mellem redaktionens medlemmer, fandtes dog en løsning på problemet. Der blev nu forud for årsmøderne udsendt særskilt meddelelse til medlemmerne, hvori der foruden årsmødeindbydelsen også var oplysninger om foreningens øvrige arrangementer i løbet af sommer og efterår, ligesom vore nye bøger foromtaltes her. Fra 1972 er Sønderjyske Årbøger derefter omkring 1. december blevet udsendt $\mathrm{i}$ et rødbrunt stift lærredsbind med smudsomslag, der stadig prydes med et billede, som regel et, der har relation til en af årbogens artikler.

Det var med glæde, at jeg så denne reform gennemført, og da jeg nu i et fortrinligt samarbejde med Fanø såvel med hensyn til ydre som indhold havde fået årbøgerne i en skikkelse, som jeg kunne ønske mig og tillige følte, at det nu måtte være på tide, at der kom yngre kræfter ind i redaktionen, som havde andre og yngre kontakter inden for den historiske verden, trådte jeg ud af denne, hvor jeg havde virket $i$ årene 1946-73, altså i en periode på 27 år. Medarbejderskabet her havde bragt mig smukke oplevelser, ikke blot i samarbejdet inden for redaktionen, men også med de mange forfattere, som jeg gennem dette arbejde lærte at kende. Jeg havde lært ikke blot mange lokalhistoriske forfattere at kende, men havde også stiftet bekendtskab med faghistorikere, som jeg måske ellers ikke ville have haft mulighed for at komme i kontakt med.

\section{Lidt økonomi}

Årbøgernes omfang skulle normalt være på 20 ark, altså 320 sider årligt, men økonomien tillod ikke altid, at dette omfang kunne overholdes. Selv om trykkeomkostningerne kunne synes lave i sammenligning med i dag, kunne de dog normalt ikke dækkes af medlemskontingentet, hvilket egentlig var tilsigtet. Kun ved tilskud fra en statsbevilling, fra Dansk Kultursamfund og ved hjælp fra anden side lykkedes det at få regnskabet til at balancere. Redaktionen måtte derfor udvise den største sparsommelighed både med hensyn til udstyr og forfatterhonorarer. Fra 1945 til ind i 1950'erne var honoraret seks kroner pr. normalside, hvilket vel ofte ikke dækkede de omkostninger, forfatterne havde haft $\mathrm{i}$ forbindelse med udarbejdelsen af manuskripterne. Men heldigvis var honorarets størrelse ikke alfa og omega for forfatterne, der som regel var interessseret $\mathrm{i}$ at fă deres manuskripter publiceret.

I og for sig kan det synes lidt ejendommeligt, at det næsten altid har været 


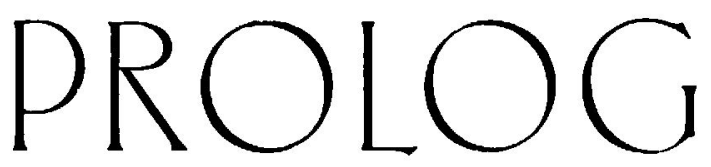

AF

MARTIN N. HANSEN

SØNDERJYSKE ÅRBØGER

$1889-1964$ 


\section{IV}

Der er sol over vang, og de vårgrønne banker bekræfter vort håb om en grødefuld tid, hvor hver forskende sjæl med frimodige tanker ser slægternes færd under modgang og strid -

da vi står på de steder, hvor blændet og blindet af minderne alt fik en skærende lyd, for at møde en dagning med tryghed $i$ sindet og vender vort blik med fortrostning mod syd.

Vi har lidt under slægternes sorgtunge skæbne og møder vor dag med en lysere tro.

For som tiderne skifter og går, må vi væbne vort hjerte med tillid til alt, der skal gro.

Vi skal leve ved grænsen foruden at glemme det hjerte, der slog i de kæmpendes bryst, og må hævde vort hjemlige præg med en stemme så karsk og frimodig som fædrenes røst.

Ved Senderjyske Arbøgers 75-\&rs jubiloum, der blev tilborlig fejret pà Folkehjem den 31, maj 1964 i overvarelse af kulturminister Julius Bomholt, havde man formdet den sonderjyske folkemalsdigter Martin N. Hansen til at skrive en prolog, som bla. indeholdt sangen: Der er sol over vang. Den er senere optaget $i$ Hojskolesangbogens senderjyske tillag. 
og måske også fremover vil være muligt at skaffe de fornødne tilskud til trykning og udgivelse, medens det, når der har været smalhans, næsten altid har været forfatterne, der har måttet undgælde. Andeligt arbejde værdsættes ikke altid på samme måde som håndens. Efterhånden blev honorarerne dog sat noget i vejret. I maj 1965 blev det således forhøjet fra 16 til $24 \mathrm{kr}$. for en normalside, medens der for sider med petit blev betalt $32 \mathrm{kr}$. Sidst i min periode, altså til 1973 har honoraret været $40 \mathrm{kr}$. pr. side, hvilket i sammenligning med den almindelige prisudvikling fra 1946 må siges at ligge i underkanten.

Ligesom honorarerne er også trykkeudgifterne naturligvis steget. Medens den tekniske fremstilling af årbøgerne endnu ved min overtagelse af redaktionssekretærhvervet lå på omkring $7.000 \mathrm{kr}$., steg prisen i løbet af nogle år til ca. 9.000 kr. 1950-51, 1960-61 var man nået op på ca. 25.000 kr., de 30.000 kr. passeredes allerede 1962-63, 1969-70 har man passeret de $40.000 \mathrm{kr}$., og ved min udtrædelse af redaktionen 1973 var man nået de $50.000 \mathrm{kr}$., altså mere end en syvdobling i løbet af 27 år. I samme periode steg medlemskontingentet fra 5,60 kr. i 1946 til $30 \mathrm{kr}$. + forsendelse i 1973. På grund af det voksende medlemstal har stigningen her været forholdsvis mindre end for trykkeudgifternes vedkommende. Der ligger altså en klar interesse i for styrelse og medlemmer at søge at hverve nye.

\section{Afsluttende bemærkninger}

Med glæde og taknemmelighed kan jeg se tilbage på de 27 år, 1946-73, jeg har medvirket i Sønderjyske Årbøgers redaktion og de 47 år, fra 1942-89, hvor jeg næsten hvert år har kunnet bidrage med en artikel, en anmeldelse eller andet stof. Vel i 30 år eller mere har jeg i hvert fald bidraget med Historisk Samfunds årsberetning, og jeg kan vist roligt bemærke, at det efterhånden kunne falde lidt trivielt at skulle skrive denne. Jeg kan med nogen ret sige, at årbøgerne har været en betydningsfuld del af min dagligdag, hvad enten jeg har brugt dem som redskab i mit daglige arbejde, eller jeg selv har leveret stof til dem. 